\title{
Parental Reading Beliefs and Children's Reading Performance
}

\author{
Amirah Jazimah Sabjan \\ Kulliyyah of Education, \\ International Islamic University Malaysia \\ Kuala Lumpur \\ amirahjazimahsabjan@yahoo.com
}

\begin{abstract}
This study explored parents' beliefs about reading and the likely association between their beliefs and children's reading performance. It employed the cross-sectional survey method with a convenience sample of 30 parents as the respondents. The sample comprised parents whose children were attending a public primary school in Gombak. The instrument was a 38-item questionnaire about parental reading beliefs adapted from DeBaryshe and Binder (1994). It consisted of five factors related to parental reading beliefs, namely teaching efficacy, positive attitude, verbal participation, reading instruction and basic knowledge. In order to measure reading performance, the parents were asked to state their children's test scores in reading comprehension at the end of the questionnaire. The relationships between the five aspects of parental reading beliefs and reading performance were analysed using Pearson correlation. The results showed that all the factors under parental reading beliefs had a positive relationship with children's reading performance, except for one factor which was reading instruction. However, none of the relationships was statistically significant.
\end{abstract}

Keywords: Islamic Parental reading beliefs, reading performance, reading instruction, teaching efficacy, verbal participation

\section{INTRODUCTION}

The two main proponents of social constructivism, Vygotsky and Dewey, believed that children learn better if they are engaged in social interaction (Glassman, 2001). There is truth in that statement as by interacting with others, children are able to widen their imagination and increase their knowledge. During reading time with parents, children are able to discuss many things with more knowledgeable adults, who will in return supply the information they need. The theory of social constructivism by Lev Vygotsky is a suitable theory to be used as the foundation for this study as it explains how parental reading beliefs affect children's reading performance. Constructivists have affirmed that the environment and social interaction play important roles in facilitating the construction and negotiation of meaning among people (Amineh \& Asl, 2015). It is very true because if children live in an environment with many literacy opportunities, they will gradually learn to love reading. In other words, children's reading performance will be enhanced when they interact with their parents, especially during their shared book reading time.

Many scholars have proven that not only do socioeconomic status and cultural beliefs affect a child's literacy development, but parenting styles and parental reading beliefs can also 
induce the child's literacy progress (McBride-Chang, 2014). This is because after school hours, children spend most of their time at home or with their parents, hence, parental factors must not be overlooked in the subject matter of enhancing a child's reading ability. Parents who have positive experiences in the past will usually create the very same experience for their children, while parents who have had negative experiences tend to provide alternatives for their children (Battleson, 2002). Parents who have had positive experiences, such as having the time to read together with their parents, having a room to study, and having a desk to read books at, will usually provide the very same environment for their kids. The same goes with parents who were not able to obtain similar positive experiences earlier. These parents tend to search for ways to provide better experiences for their children so that the children will perform better than they did.

Conlon et al. (2006) proposed that parental reading experiences and parental reading habits will most likely influence children's reading performance. This is because parents' previous experiences may provide the knowledge they need to assist their children's reading development. For instance, parents who are acquainted with the library and often go there during weekends will definitely bring their children along as they know that the children will be persuaded to read in an environment where all others around them are engaged in reading. In addition to that, parents' habit of going to the library is indeed a good practice because it exposes children to a wide variety of genres and reading materials. Hence, they will not be restricted to a certain genre or a specific kind of books. The best part of it would be they do not have to pay for the reading material.

Some parents read together with their children, and this practice helps develop children's reading ability and interest (Sokolinski, 2014). Parents who discuss the stories they read in the past can affect their children's perception of and relationship with books. This is because children can be motivated and triggered to do the very same activities their parents engaged in, or they may want to do something entirely different to show that they can be better than their parents. At the same time, parents and teachers should be realistic in their expectations of children's reading performance, especially if the concerned children have learning disabilities (Maughan et al., 2009). Parents who are responsible for their children's achievement at home and teachers who are accountable for their students' performance at school should not set too high an expectation because every child differs from one another in progress.

When discussing children, their reading habits and performance, the issue of attitude should not be left untouched. Children who have a positive attitude towards reading will usually perform better in tests (Logan \& Johnston, 2009). This is why parents should join in and lend a hand to their children by instilling positive attitudes towards reading, such as telling them that reading brings pleasure and reading is fun. When children have developed a positive attitude towards reading, they will not have problems to read texts, to understand writings and to answer questions which they need to do in their reading comprehension tests. Studies about how affective factors, such as reading attitude, are connected to reading performance have become the interest of many scholars nowadays (Martinez, Aricak \& Jewell, 2008). It has become an important topic because people know that in order to succeed, they need to have a positive attitude. For children to have the right, positive attitudes, parents as the closest members of the family can guide in various ways for example, by imparting the ideas that with reading, they can dream big, embark on adventures, and let their imagination run free.

Research suggests that active readers usually develop in their minds an inner dialogue with the text through mental activities like summing up, making connections, and questioning ideas specified in the material (Paul \& Elder, 2006). These practices aid children's understanding of the text, hence improving their chances to perform well in their reading 
comprehension exercises and tests. Parents can assist children's text comprehension by reading aloud, at the same time asking each other questions so that it becomes a habit. After some time, the children will develop the skills of questioning and connecting ideas on their own while reading.

Closely associated with reading habits and practices are the terms strategic readers and ordinary readers. When facing hiccups in reading, strategic readers will generate alternative actions in order to proceed with the reading activity. Ordinary readers, on the other hand, will resort to sleeping or any other act of giving up due to the lack of strategies in encountering a text's difficulties (Afflerbach, Pearson \& Paris, 2008). Strategic readers do not only put in a lot of hard work in understanding a text, but they also have techniques for letter identification and strategies to answer comprehension tests. In short, students who find it difficult to read due to varying factors can be taught to utilize these strategies to help them comprehend text material. In a Taiwanese study, Wu (2012) tested an extensive reading strategy on children, and the intervention resulted in positive outcomes on the children's reading performance. An extensive reading strategy is a method used to absorb information from various text materials, and to comprehend and analyse the language used by the writer. This strategy turns out to be useful because children will be able to indulge themselves with a variety of books that are not available at home.

In the meantime, because schools have been given the responsibilities to teach students fundamental literacy skills, teachers must exert a lot of effort to ensure that students acquire these skills and improve their reading performance. In the current context of schooling, teachers need to join forces with parents by making them more aware of their role in facilitating the education of their children (Souto-Manning \& Swick, 2006). For instance, it is not unusual for us to see teachers who encourage parents to have a short but quality session of reading together as it will help tremendously in improving their children's reading skills. Parents do not have to take a very long time to teach their children, but they should consistently do so. Eventually, children can grasp the habit of reading and with time, they will learn to love reading.

Given the importance of reading, more studies should be done on how parental beliefs about literacy development are related to home literacy environment and children's reading performance (Weigel, Martin \& Bennett, 2006). Hence, this present study is expected to fill the research gap as its results can provide some information on the connection between parental beliefs and children's literacy development. As children spend most of their time at home after school, parents should expose their children to books, as well as other reading materials, to develop the habit of and the love for reading. Parents should create enough literacy opportunities at home so that their children's development will not be hampered (Battleson, 2002). Chances for literacy development should be provided--such as spending some time together to read books, buying children interesting materials for any kind of celebration and providing them a study room or reading area just to inculcate within them the habit of reading, be it reading for pleasure or reading for school.

Based on previous research, much attention has been given to the area of improving reading skills among learners, but still many people find it hard to read (Martinez, Aricak \& Jewell, 2008). Reading can be seen as a starting point to academic success. If one cannot read, then one will probably have difficulties in writing, and also, in speaking. There must be reasons as to why people find it difficult to read. This current study intends to shed some light on the reasons why people dislike reading. The purpose of this study was to look at parental reading beliefs and how they might be associated with children's reading performance. This research 
was conducted among primary school students as it is believed that reading skills should be acquired from an early stage of life. With the reading issues discussed above as the backdrop, this study was, therefore, an attempt to explore more about the association between parental reading beliefs and reading performance among children in a Malaysian public school.

\section{METHODOLOGY}

\section{Research Design}

This research employed the cross-sectional survey design that aimed to look at parental reading beliefs and their association with children's reading performance. This study was conducted in a Malaysian public primary school. An adapted questionnaire with a slight modification was used as an instrument for this research. The parents were required to answer the questionnaire regarding their reading beliefs and their children's reading performance.

\section{Population and Sample}

The population for this research comprised the school children attending a Malaysian public primary school in Sungai Pusu, Gombak. In 2017, the school had approximately 688 male students and 675 female students studying in Year 1 to Year 6. Each grade level had six classes, making up a total of 36 classes altogether. For this study, the parents of Year 6 students were chosen as the sample. At the time of data collection, all of the Year 6 students had taken the standardized UPSR examination in September 2017.

\section{Sampling Procedure and Ethical Consideration}

Convenience sampling, a non-probability sampling procedure, was utilised to select the sample. The researcher visited the school and selected Year 6 students who were available during her visit. The researcher first wrote a letter to the public primary school requesting a permission to conduct the study. Once permission was granted, the researcher approached some Year 6 class teachers to distribute the questionnaires to the students who were requested to take them home for their parents to fill out.

\section{Instrument}

The instrument used was a 38-item Likert questionnaire adapted from DeBaryshe and Binder (1994) (Appendix A). It consisted of two parts: A and B. Part A measured parental reading beliefs in five aspects, namely teaching efficacy, positive attitude, verbal participation, reading instruction and basic knowledge. Part B measured children's reading comprehension. It required parents to respond to two items requesting the marks of their children's reading comprehension, and their comments and opinions on the issue. The breakdown of the questionnaire items by construct is given in Table 1 . 
Table 1

Parental Reading Beliefs Questionnaire

\begin{tabular}{|c|c|c|c|}
\hline Part & Aspect & No of Items & Sample Items \\
\hline \multirow{5}{*}{$\begin{array}{l}\text { Part One: } \\
\text { Parental Reading } \\
\text { Beliefs } \\
\text { (36 items) }\end{array}$} & Teaching efficacy & 9 & $\begin{array}{l}\text { - Children do better in school when their } \\
\text { parents also teach them at home. }\end{array}$ \\
\hline & Positive attitude & 9 & $\begin{array}{l}\text { - Reading with my child is a special } \\
\text { time that we love to share }\end{array}$ \\
\hline & Verbal participation & 9 & $\begin{array}{l}\text { - When we read, I try to sound excited } \\
\text { so my child stays interested }\end{array}$ \\
\hline & Reading instruction & 4 & $\begin{array}{l}\text { - Parents should teach children how to } \\
\text { read before they start school. }\end{array}$ \\
\hline & Basic knowledge & 5 & $\begin{array}{l}\text { - Reading helps children learn about } \\
\text { things they never see in real life. }\end{array}$ \\
\hline \multicolumn{4}{|l|}{ Part Two: } \\
\hline $\begin{array}{l}\text { Children's Reading } \\
\text { Comprehension }\end{array}$ & & 1 & $\begin{array}{l}\text { - Please indicate your child's reading } \\
\text { comprehension score: }\end{array}$ \\
\hline Parents' Opinions & & 1 & Open response \\
\hline
\end{tabular}

\section{Data Collection}

Copies of the questionnaire were given to the students to take home to their parents to fill up. The data collection was conducted in two days. On the second day, completed questionnaires were collected from 11 boys and 19 girls, representing 30 parents who participated in the survey. The parents, sampled via convenience sampling, were invited to participate in the survey by responding to the 38 items. They needed to mark the extent to which they agreed and disagreed with the questions. They also wrote down their views about the issue of their own reading beliefs and their children's reading performance. The completed questionnaires were collected the next day from the students.

\section{Validity and Reliability}

The questionnaire items' content validity was established via expert judgment provided by a panel of experts from the Department of Language and Literacy, IIUM. The ideas and the items were checked for constructive alignment with the definitions they carried. The experts' advice was taken into account to improve the instrument, making sure that it measured what it was intended to measure which, in this context, were parents' beliefs about reading and the reading performance of children. The items were revised and modified several times before they were given to the respondents. In terms of reliability, DeBaryshe and Binder (1994) reported a Cronbach's alpha of .73 for the teaching efficacy construct, .85 for positive attitude, .83 for verbal participation, .63 for reading instruction, and .82 for basic knowledge. 


\section{Data Analysis}

All collected data were tabulated and analysed using The Statistical Package for the Social Science (SPSS) software. Scores representing each of the five aspects of parental reading beliefs were summated from their respective items, while the total score representing parental reading beliefs was obtained by totalling the scores of the five aspects. Pearson correlation was used to answer the research question on whether the five aspects of parental reading beliefs were significantly associated with children's reading performance.

\section{RESULTS}

Table 2 shows the correlations between parental reading beliefs, as well as its five aspects, and children's reading performance.

Table 2

Correlation between Parental Reading Beliefs and Children's Reading Performance $(\mathrm{N}=30)$

\begin{tabular}{lcc}
\multicolumn{1}{c}{ Constructs } & $\begin{array}{c}\text { Pearson } \\
\text { Coefficient } \\
\text { (r) }\end{array}$ & $\begin{array}{c}\text { Sig. } \\
\text { (2-tailed) }\end{array}$ \\
\hline Relationship between Children's Reading Performance and & & \\
1. Parental Reading Beliefs & .163 & .390 \\
2. Teaching Efficacy & .018 & .923 \\
3. Positive Attitude & .197 & .296 \\
4. Verbal Participation & .014 & .943 \\
5. Reading Instruction & -.158 & .406 \\
6. Basic Knowledge & .306 & .100
\end{tabular}

Parental reading beliefs had a positive relationship with children's reading performance, but the relationship was not statistically significant, $(r=.163, p=.390>.05)$. Additionally, four of the five aspects of reading beliefs demonstrated a similar positive relationship, but it was not statistically significant.

As indicated in Table 2, the correlation between teaching efficacy--the first aspect of parental reading beliefs--and children's reading performance was positive but not significant $(\mathrm{r}=.018, \mathrm{p}=.923>.05)$. Items 1 to 9 in the questionnaire (Appendix A) dealt with the teaching efficacy factor. In this factor, three items (i.e., 8, 2 and 7) grabbed the parents' attention. In response to item 8 , which was "When my child goes to school, the teacher will teach my child everything he needs to know so I don't need to worry", the parents stated that they would "leave it all to the teachers..." To item 2, "There is little I can do to help my child get ready to do well in school", the parents indicated they "could not help much in science and mathematics subjects." To item 7 (i.e., "Parents need to be involved in their children's education"), the parents offered that they did "some science experiments in their back yard..."

The correlation between positive attitude, which was the second factor under parental reading beliefs, and children's reading performance was also positive, but not statistically 
significant $(r=.197, p=.296>.05)$. Items 10 to 20 in the questionnaire measured positive attitude. Two items on positive attitude (i.e., items 11 and 13) drew a reaction from the parents. Fathers indicated that "Usually, their mother will help them..." as a response to item 13 that stated "Reading with my child is a special time that we love to share". Responding to item 11, "I enjoy reading with my child," they mentioned "read[ing] newspapers" with their children.

Table 2 also displays the correlation between verbal participation, the third factor under parental reading beliefs, and children's reading performance. Similarly, verbal participation demonstrated a positive but non-significant relationship with reading performance $(\mathrm{r}=.014$, $\mathrm{p}=.943>.05$ ). Items 19 to 27 in the questionnaire focused on the verbal participation factor. In this factor, only one item (i.e., item 20) prompted the parents to give an opinion. In response to item 20 ("When we read, I try to sound excited so my child stays interested"), the parents specified that they did try a few techniques to maintain their children's interest in the reading activity, which included making "sounds" in the storytelling.

Reading instruction--the fourth underlying factor of parental reading beliefs--was inversely and not significantly associated with reading performance, $(\mathrm{r}=-.158, \mathrm{p}=.406>.05)$. Items 28 to 31 in the questionnaire assessed the reading instruction factor. This was the only factor that the parents had not commented on. Finally, the correlation between basic knowledge-the fifth factor under parental reading beliefs--and reading performance was also found to be positive but not significant $(\mathrm{r}=.306, \mathrm{p}=.100>.05)$. Regarding basic knowledge, the parents shared that their children "learn [ed] a lot from $T V$ " rather than from books.

\section{DISCUSSION}

Based on the results of this study, parental reading beliefs can generally be concluded to have a positive relationship with reading performance, although the association was weak and statistically not significant. Four out of five aspects of reading beliefs, namely teaching efficacy, positive attitude, verbal participation, and basic knowledge, were positively correlated with reading comprehension. Only one aspect--reading instruction--was negatively associated. The results could be due to the very small sample size of merely 30 parents. Nonetheless, to understand the results better, it is best to look at the factors categorized under parental reading beliefs one by one.

Factor one, which was teaching efficacy, had a positive relationship with children's reading performance, but the relationship was of no statistical significance. Teaching efficacy here may refer to whether the parents have the ability to play their role as teachers at home (Teng, 2014). Some of the children considered their parents as teachers because at home, either their mother or father would teach them subjects like Malay Language and English Language. With parental guidance, the children were able to improve their achievement in school. The results are supported by Woods (2017) who conducted a parent training program and found that when children regarded their parents as teachers, they scored much higher in the tests. Woods' observation suggested that parents in general were positive and helpful in assisting children to study or to read. Other than the numerical data gained from the questionnaire, the parents also provided their viewpoints for several items given in the survey. In response to item 8, "When my child goes to school, the teacher will teach my child everything he needs to know so I don't need to worry", the parents said they would "leave it all to teachers...". This could be understood from looking at the busy schedule that most parents have today which gives them little time to read to and with their children. 
Fortunately, the parents still made an effort to participate in most school programs to support their children's academic development. On the other hand, there were also uneducated parents who catered to all their children's needs, except for the academic part, because they did not know how to assist academically due to their own lack of education. Some of the parents specifically indicated their lack of ability to help in science and mathematics subjects. This could be because many concepts in science and mathematics might not be familiar to the parents as the current syllabi for the two subjects had significantly changed over time and were different from what the parents had learned during their school days. Hence, the parents were not able to assist their children in understanding the content as they themselves lacked knowledge and familiarity with the materials prescribed in the current curriculum.

Parental involvement in children's learning critically affects their academic output and success. Pinantoan (2016) wrote, "Students with two parents operating in supportive roles are $52 \%$ more likely to enjoy school and get straight As than students whose parents are disengaged with what's going on at school. This is especially the case during the earliest years of schooling, in kindergarten through the 5th grade, when students with active parents are almost twice as likely to succeed." The observation made by Pinantoan (2016) found some support in this study. To illustrate, in response to item 7 which said, "Parents need to be involved in their children's education," the parent of one student mentioned that they did some science experiments in their backyard. This particular student obtained the highest mark for his comprehension test which was 90 out of 100. The parents of this student were very active in assisting their children to read and study where every activity that was doable would be done by them together at home. The effectiveness of this involvement is manifested in the student's reading performance.

Factor two, which was positive attitude, had a positive relationship with children's reading performance, although not significant. Positive attitude here means having a positive view of reading, and it can be expressed in terms of behaviour, cognition and emotion (DeBaryshe \& Binder, 1994). Many parents in the survey had a positive attitude towards reading, and that helped the reading performance of their children. In addition, in the comment section, the male respondents indicated the role of the other parent--the mother--in reading with their respective child, which they regarded as a special time of sharing. The reason for this is that most fathers tend to be strict in character. Consequently, children tend to feel more comfortable reading with their mothers rather than their fathers. This finding is in line with Teng (2014) who found parental beliefs to, indeed, affect home literacy practices, and that fathers' role was comparatively less significant than mothers' role in producing an environment imbued with literacy opportunities. In most cases, children are more relaxed reading with their mothers than with their fathers. Besides this, the parents informed that they read newspapers with the children, an activity that helped children to broaden their horizon, acquire new vocabulary, and develop a love for reading.

Verbal participation in this study was found to be positively but not significantly associated with reading performance. Verbal participation is the third aspect of parental reading beliefs, and can be defined as parents' use of voices, sounds and words in reading activities with children (Teng, 2014). Most of the parents participated verbally during their reading time and it contributed to their children's reading performance. In the opinion section, the parents informed that they attempted to enhance the reading session with their children by making sounds and voices for the characters in the story being read. They tried to imitate the sounds of animals, ghosts and famous people, including male and female figures. They tried their best to make the reading time enjoyable so the children could stay interested. Another study by Weigel, Martin and Bennett (2005) supported this study's result as they agreed that one important 
routine that can enhance children's literacy development is when parents interact verbally with their children while reading together at home. Hence, it can reasonably be concluded that verbal participation can indeed help children to perform better in their reading comprehension ability.

The fourth factor, reading instruction, means giving directions to children and teaching them while reading (DeBaryshe \& Binder, 1994). This was the only factor that was negatively associated with children's reading performance. This might mean that explicit instruction in alphabet, letter or word recognition during the reading process does not necessarily increase comprehension. In fact, according to what the evidence suggests, this instruction when it is done interrupts children's information processing and hampers their comprehension of the story or reading material. This explains the negative relationship between reading instruction and reading comprehension. The children might dislike it when their parents gave instruction while reading. It was more likely that they preferred to enjoy reading without being interrupted by explicit instruction. The instruction could have detracted the value and enjoyment found in the reading activity as the more reading instruction they received, the less they comprehended the materials.

A different perspective on reading instruction was offered in Bechard, Hesselrode and Sanders (2015). Their findings indicated that reading instruction helped children to obtain high scores in comprehension tests, partly because teachers were able to give high quality reading instruction after a professional training programme. Thus, Bechard et al. (2015) and this present study differ in that in the former study, the teachers were trained to give correct instruction during reading, and knew what kind of instructions would enhance or hinder comprehension. On the contrary, parents who took the survey in the present research did not know the correct nature of reading instruction, hence the more reading instruction they gave, the less likely the children would perform in reading comprehension as the instruction tend to hamper comprehension rather than boost it.

Basic knowledge, defined as the information children gain from the books read together with parents or under parents' supervision (Teng, 2014), was positively but not significantly correlated with reading performance. Quite a number of the children gained information from the books as well as their parents and that definitely helped to improve their reading performance in school. Another study proposed that children integrated new knowledge with their existing knowledge and when they read with their parents, that would be the time where they were able to expand and modify the knowledge they acquired from other places (Teng, 2014).

Teng's observations are similar to the present study as some parents in the selected primary school involved in this research read together with their children, and allowed their children to watch television just to increase their knowledge. At the same time, while reading together, they initiated a responsive conversation and responded to their children's inquiries. In a commentary, some parents pointed to broadcast media, i.e. television, as an important source of knowledge for children. Among low socioeconomic children who had no regular access to the Internet and rarely or never travelled, television was their primary means of learning certain skills and acquiring knowledge about other countries and cultures.

The results allow the study to summarise that Malaysian parents nowadays practise reading together with their children, and encourage them to read for academic purposes. Children most of the time are asked to read materials that are academic in nature. 
The materials that are not related to their school syllabus are not encouraged to be read by the children. This condition put on the reading materials allowed to children has, in a way, hampered their motivation to read materials that they find interesting. It is not unlikely that they would prefer to read books outside their syllabus, such as books about cars, cooking, adventures and aliens, whose subject matter appeals to their interest and curiosity. Children enjoy themselves while reading books of this nature, and their imagination also runs wild and becomes creative at the same time. Therefore, it must be asserted that reading should not be restricted to academic purposes only; it should also be done for pleasure and knowledge seeking. Academic reading is important for children's grades and school performance, but reading for pleasure is also necessary for their cognitive development. In short, parents must help their children in balancing their reading habits and interest. Parents can assist in managing children's time in terms of how much they should spend on academic and school-related reading, and how much they should spend on reading for pleasure.

\section{CONCLUSION}

In conclusion, although this study was a preliminary one, there were positive results that should be taken into account. All of the factors under parental reading beliefs, namely teaching efficacy, positive attitude, verbal participation and basic knowledge had a positive relationship with children's reading performance. The only factor that had a negative association with it was reading instruction. Although the results were not significant, some insights were gained on what Malaysian parents believed to be good reading practices. The results could be used to affirm the utility of aspects like teaching efficacy, positive attitude, verbal participation and basic knowledge in influencing reading comprehension among children. Thus, these aspects should be practised or continue to be practised by parents at home as they have clear benefits for children's academic achievement.

Based on the results, the study contrived a principle on reading beliefs and reading performance acronymed as "THP". In this principle, $T$ stands for time. What it means is parents do not have to spend a very long time every day to shape their children into the habit of reading. They can just spend 5 to 10 minutes per day to read together. Consistency in spending this amount of time daily, albeit short, will gradually lead to a fruitful impact on their children's reading interest and achievement. The next rule, $H$, stands for habit. When parents are consistent in spending time to read with their children, that activity will develop into a habit that crystallises over time. When good reading habits are crystallised in children, parents are spared from having to force them to read when they are older because it has become a routine for them. Lastly, $P$ stands for progress. Progress differs from one child to another. Parents must not push their children. Instead they should support them through every level of their life. Parents must follow their pace and give assistance whenever it is necessary. Knowing children's capabilities and weaknesses are important so that parents can maximize and maintain their strengths, and provide them with the correct mechanisms to overcome their shortcomings. 


\section{REFERENCES}

Afflerbach, P., Pearson, P. D., \& Paris, S. G. (2008). Clarifying differences between reading skills and reading strategies. The reading teacher, 61(5), 364-373.

Amineh, R. J., \& Asl, H. D. (2015). Review of constructivism and social constructivism. Journal of Social Sciences, Literature and Languages, 1(1), 9-16.

Battleson, R. A. (2002). The discovery of the beliefs, attitudes, practices and communications about family literacy of three families with children experiencing difficulties in literacy development (Doctoral dissertation, University of Northern Colorado).

Bechard, H.,Hesselrode, M. \& Sanders, C. (2015). The Effect of Preston Taylor Ministries' Reading Interventions on Students' Performance, Motivation, and Confidence Related to Reading (Doctoral dissertation, Lipscomb University).

Conlon, E. G., Zimmer-Gembeck, M. J., Creed, P. A., \& Tucker, M. (2006). Family history, self-perceptions, attitudes and cognitive abilities are associated with early adolescent reading skills. Journal of Research in Reading, 29(1), 11-32.

DeBaryshe, B. D., \& Binder, J. C. (1994). Development of an instrument for measuring parental beliefs about reading aloud to young children. Perceptual and Motor Skills, 78(3_suppl), 1303-1311.

Glassman, M. (2001). Dewey and Vygotsky: Society, experience, and inquiry in Educational practice. Educational researcher, 30(4), 3-14.

Logan, S., \& Johnston, R. (2009). Gender differences in reading ability and attitudes: Examining where these differences lie. Journal of Research in Reading, 32(2), 199-214.

Martinez, R. S., Aricak, O. T., \& Jewell, J. (2008). Influence of reading attitude on reading achievement: A test of the temporal-interaction model. Psychology in the Schools, 45(10), 1010-1023.

Maughan, B., Messer, J., Collishaw, S., Pickles, A., Snowling, M., Yule, W., \& Rutter, M. (2009). Persistence of literacy problems: spelling in adolescence and at midlife. Journal of Child Psychology and Psychiatry, 50(8), 893-901.

McBride-Chang, C. (2014). Children's literacy development. New York, NY: Routledge.

Paul, R., \& Elder, L. (2006). Critical Thinking Reading \& Writing Test. Tomales, CA: Foundation for Critical Thinking.

Pinantoan, A. (2016). The Effect of Parental Involvement on Academic Achievement. TeachThought. Retrieved from https:/www.teachthought.com/learning/the-effect-ofparental-involvement-on-academic-achievement/

Sokolinski, S. A. (2014). "Nothing is greater to a child, I think, than a teacher and the parent coming together for their sake": A critical examination of one mother's beliefs about reading (Doctoral dissertation, Northern Illinois University). 
Souto-Manning, M., \& Swick, K. J. (2006). Teachers' beliefs about parent and family involvement: Rethinking our family involvement paradigm. Early Childhood Education Journal, 34(2), 187-193.

Teng, W. (2014). Parental reading beliefs, home literacy practices, and children's development: Examination of a parental reading beliefs model in China (Doctoral dissertation, University of the Pacific).

Weigel, D. J., Martin, S. S., \& Bennett, K. K. (2005). Ecological influences of the home and the child-care center on preschool-age children's literacy development. Reading Research Quarterly, 40(2), 204-233.

Weigel, D. J., Martin, S. S., \& Bennett, K. K. (2006). Mothers' literacy beliefs: Connections with the home literacy environment and pre-school children's literacy development. Journal of Early Childhood Literacy, 6(2), 191-211.

Woods, L. S. (2017). Interactive Book Reading: Promoting Emergent Literacy Skills in Preschool Children through a Parent Training Program (Doctoral dissertation, The University of North Carolina at Chapel Hill).

$\mathrm{Wu}, \mathrm{J}$. (2012). The influence of extensive reading on junior high school students' reading motivation and reading performance in Taiwan (Doctoral dissertation, Colorado State University Libraries). 


\section{APPENDIX A: QUESTIONNAIRE}

\section{PRBI (Parental Reading Beliefs Inventory)}

\section{Part One}

Listed below are several statements about parent's attitudes and beliefs. Circle the answer that is closest to your feelings. Please answer each question in regard to your child. There are no right or wrong answers. Your opinions are important to us.

\begin{tabular}{|c|c|c|c|c|c|c|}
\hline \multirow{2}{*}{ No. } & \multirow{2}{*}{ Items } & 1 & 2 & 3 & 4 & 5 \\
\hline & & SD & $\mathrm{D}$ & $\mathrm{N}$ & A & SA \\
\hline 1 & $\begin{array}{l}\text { As a parent, I play an important role in my child's } \\
\text { development. }\end{array}$ & & & & & \\
\hline 2 & $\begin{array}{l}\text { There is little I can do to help my child get ready to do well } \\
\text { in school. }\end{array}$ & & & & & \\
\hline 3 & My child learns many important things from me. & & & & & \\
\hline 4 & I would like to help my child learn, but I don't know how. & & & & & \\
\hline 5 & I am my child's most important teacher. & & & & & \\
\hline 6 & Schools are responsible for teaching children, not parents. & & & & & \\
\hline 7 & Parents need to be involved in their children's education. & & & & & \\
\hline 8 & $\begin{array}{l}\text { When my child goes to school, the teacher will teach my } \\
\text { child everything my child needs to know so I don't need to } \\
\text { worry. }\end{array}$ & & & & & \\
\hline 9 & $\begin{array}{l}\text { Children do better in school when their parents also teach } \\
\text { them things at home. }\end{array}$ & & & & & \\
\hline 10 & I find it boring or difficult to read to my child. & & & & & \\
\hline 11 & I enjoy reading with my child. & & & & & \\
\hline 12 & I have good memories of being read to when I was a child. & & & & & \\
\hline 13 & $\begin{array}{l}\text { Reading with my child is a special time that we love to } \\
\text { share. }\end{array}$ & & & & & \\
\hline 14 & My child does not like to be read to. & & & & & \\
\hline 15 & I feel warm and close to my child when we read. & & & & & \\
\hline 16 & I have to scold or discipline my child when we try to read. & & & & & \\
\hline 17 & I want my child to love books. & & & & & \\
\hline 18 & I don't read to my child because he or she won't sit still. & & & & & \\
\hline 19 & I read to my child whenever he or she wants. & & & & & \\
\hline 20 & $\begin{array}{l}\text { When we read I try to sound excited so my child stays } \\
\text { interested. }\end{array}$ & & & & & \\
\hline 21 & Children learn new words, colors, names, etc. from books. & & & & & \\
\hline
\end{tabular}




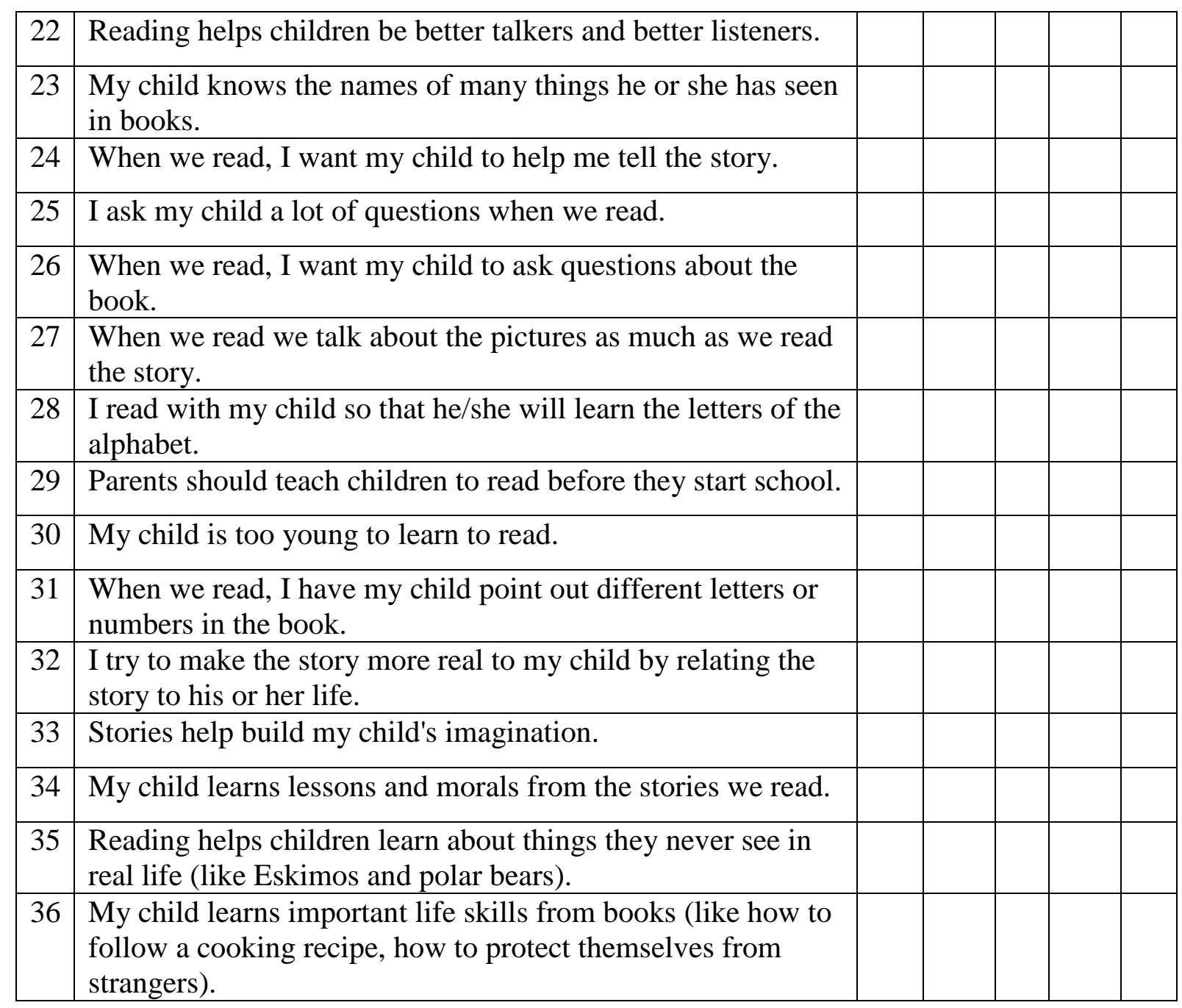

\section{Part Two}

Your Child's Reading Comprehension Score:

Comments: 